\title{
Evaluation of Different Measures of Milk Yield Persistency in Iranian Holstein Dairy Cows
}

\author{
Mahdi Elahi Torshizi (Corresponding author) \\ Department of Animal Science, Mashhad Branch, Islamic Azad University, Mashhad, \\ Iran. Tel: (+98) 9155065994 \\ Mojtaba Hosseinpour Mashhadi \\ Department of Animal Science, Mashhad Branch, Islamic Azad University, Mashhad, \\ Iran. Tel: (+98)915 5131361
}

Received: June 20, 2016

Accepted: July 10, 2016

Published: August 3, 2016

doi:10.5296/jas.v4i3.9608

URL: http://dx.doi.org/10.5296/jas.v4i3.9608

\begin{abstract}
Test-day lactation records of primiparous Holstein cows over an eleven-year period were evaluated for persistency and estimates of its heritability and correlation with other lactation traits computed. In this study, 435390 test day records of the first lactation Holstein cows that calved between 2001 and 2011 from 659 herds were analyzed using various procedures of SAS. Per1\% (dividing total milk yield between 101-200 days by the yield of the first 100 days of lactation) measure was preferred in the selection of animals for milk yield persistency because of higher heritability $(0.084 \pm 0.009)$ and the lower phenotypic correlation with 305 days milk yield (0.424) compare to other persistency measures. The result showed that cows which calved during summer and autumn had slightly higher persistency in comparison to cows that calved in spring or winter. The persistency can be affected by the age at first calving, as cows that calved at a younger age had lower persistency.
\end{abstract}

Keywords: Heritability, Lactation curve parameters, Partial milk yield, Persistency, Season of calving.

\section{Introduction}

Milk production is largely dependent on the shape of the lactation curve which reflects peak production level, time of peak, and persistency (Per). Persistency of lactation is considered a very important characteristic of the lactation curve (Cobuci et al., 2007). One of the most important key issues in persistency is the definition of this trait. There is no clear consensus on the best way of measuring persistency (Cole and VanRaden, 2006). Persistency expresses the ability of an animal to maintain a reasonably constant milk yield after the lactation peak (Strabel et al., 2001). In other words, the persistency refers to the rate of decline in yield after the peak of production. It, therefore, gives an indication of the flatness of the production 
curve and should be independent of the level of production (Mostert et al., 2008; Jensen, 2001). Cows with higher persistency use better and cheaper roughage around peak yield (Solkner and Fuchs, 1987), improvement of health (less metabolic stress; reduced probability of diseases) and fertility (Zimmermann and Sommer, 1973). It is better to calculate persistency in primiparous cows because first parity cows show an initial and peak milk yield lower than second and third parity cows, however, greater persistency compared to second and third parity cows (Togashi et al., 2008). In other words, cows in the first lactation have flatter lactation curves for milk, fat, and protein yields; with lower peak and higher persistency compared to cows in later lactations. Several measurements of persistency that have been proposed are 1) the rate of decrease of milk yield during lactation, 2) measures constructed using parameter estimates from mathematical models of lactation curves, 3) measures based on variation of test day yields 4) proportion of total milk yield achieved in a certain period and 5) evaluation of some measures using different orders of Legendre polynomials by Random regression methodology (Elahi Torshizi et al., 2013; Jakobsen et al., 2002). Gengler et al., (1996) evaluated many common definitions of persistency (measures based on ratios of yields, variation of yields and functions that describe lactation yields). Jamrozik et al., (1997) proposed measuring the average slope of an animal's lactation curve between 60 and 280 days of lactation. Druet et al., (2003) proposed that the first and second eigenvectors estimated using random regression models may be useful for describing persistency, but Togashi and Lin (2006) showed that the first three eigenvectors of the additive covariance matrix are adequate to maximize milk yield and genetic response for persistency. Based on the method of persistency evaluation, the heritability of this trait varies greatly in numerous studies. Kaygisiz et al., (1995) reported $0.500 \pm 0.204$ for heritability of milk yield persistency in dairy cattle while Jakobsen et al., (2002) estimated the heritability of persistency ranged from 0.09 to 0.24 . Kheirabadi and Alijani (2001) calculated the heritability of persistency between 0.06 and 0.22 using different measures and they reported 0.31 for heritability of 305 days milk production by multiple trait random regression model in Iranian Holstein cows. The shape of the lactation curve is affected by several factors such as herd, body weight, the age of cow, dry period, rations, the season of calving and production, temperature, and humidity (Hickson et al., 2006). Also, various factors influence persistency, but parity seems to have the greatest influence. For first lactation Czech Holstein cows, Dedkova and Nemcova (2003) observed that winter calving cows had higher milk production with the lactation curve having steeper shape until peak, compared to summer and autumn calving cows. However, they reported that persistency was best for cows calving in August and September. Solkner and Fuchs (1987) obtained the same result for dairy cows by using both ratios of yields during different stages of lactation, as well as measures expressed as ratios of variation that occurred in test day yields. They also found that the season of parturition, as well as the total milk yield, had a significant effect on measures of persistency obtained through these two methods. The objectives of this study were the evaluation of lactation persistency by different methods and the study of heritability and non-genetic factors affecting this trait in Iranian primiparous Holstein cows.

\section{Material and Methods}

The originally used data included 637902 records of test day milk yield 77698 of Iranian 
primiparous Holstein dairy cattle that calved from 2001 to 2011. Data selection criteria were three to ten test day records per cow, three milkings per day, known sire and dam, age at calving was between 18 and 32 months of age (Macciotta et al., 2007) and individual daily milk production between 2.5 and $60 \mathrm{~kg}$. After editing, data consist of 435390 test day records for milk yield of 48955 dairy cows (Table 1).

The Wood's incomplete gamma function (1967) was used to fit the individual lactation curves, described as $\mathrm{y}_{\mathrm{t}}=\mathrm{at}^{\mathrm{b}} \exp ^{(-\mathrm{ct})}$. In this description, $\mathrm{y}_{\mathrm{t}}$ is the daily yield on day $\mathrm{t}$ and $\mathrm{a}$ approximates the initial milk yields after calving, $\mathrm{b}$ is the inclining slope parameter up to peak yield, and $\mathrm{c}$ is the declining slope parameter (Wood, 1967). Peak milk yield, the days at peak milk yield and total milk of 305 days were calculated as b/c, a(b/c) $)^{b} \exp ^{-b}$ and $\sum_{i=1}^{305} y_{i}$ respectively. Atypical lactation curves, which had negative values of a, b or c were not used to predict daily milk yield. The parameters of each individual curve were estimated in accordance with the non-linear procedure (PROC NLIN) of SAS (version 9.12). Moreover, partial production from days 5-100 days in milk (Part1), 101-200 days in milk (Part2), 201-305 days in milk (Part3) and total production from 5-305 days in milk (Milk 305 days) were calculated individually for each animal.

\section{Persistency}

Different measures of persistency based on partial yields were used from the literature (Gengler et al., 1996; Cakilli and Gunes, 2011; Togashi and Lin, 2004). In this study four different measures of persistency (Per1\%, Per2\%, and Per3\%) were used:

$$
\begin{aligned}
& \text { per1 } \%=\frac{\text { milk y ield between } 101-200 \text { day s after parturation }}{\text { milk yield in thefirst } 100 \text { days of the lactation }} \times 100 \\
& \text { per2\% }=\frac{\text { milk yield between } 201-305 \text { days after parturation }}{\text { milk yield in thefirst } 100 \text { day s of the lactation }} \times 100 \\
& \text { per3\% }=\frac{\text { milk y ieldbet ween } 201-305 \text { day s after parturation }}{\text { milk y ield between } 101-200 \text { days after parturation }} \times 100
\end{aligned}
$$

The effect of environmental factors and covariates on different persistency measures were investigated using analysis of variance (PROC GLM) with the following model:

$$
\mathrm{y}_{\mathrm{nijklm}}=\mu+\alpha_{\mathrm{i}}+\omega_{\mathrm{j}}+\lambda_{\mathrm{k}}+\phi_{1}+\mathrm{b}_{\mathrm{R}}\left(\text { age }_{\mathrm{ijkl}}-\overline{\mathrm{age}}\right)+\varepsilon_{\mathrm{nijklm}}
$$

Where $y_{\text {nijkl }}$ is the persistency trait of the $n^{\text {th }}$ animal affected by $i^{\text {th }}$ herd, $j^{\text {th }}$ calving year, $k^{\text {th }}$ season of milk production, $l^{\text {th }}$ season of calving, $b_{R}$ is the linear regression coefficient of age at calving (covariate) on persistency, and $\varepsilon_{\text {nijklm }}$ is the random effect of residual with expectation and variance equal to 0 and $\sigma^{2}$ erespectively. The persistency parameters were furthermore determined by using the Kamidi method (2005). This method fit is a quadratic polynomial to the cumulative milk yield of the cows. Cumulative milk yield (y) during given time $t$ is calculated by the following formula:

$$
y=\alpha+\beta t+\gamma t^{2}+\varepsilon
$$




\section{Macrothink}

Journal of Agricultural Studies

ISSN 2166-0379

2016, Vol. 4, No. 3

Where $\alpha, \beta, \gamma$ and $\varepsilon$ are intercept, a constant associated with total lactation yield, a declaration constant and the random residual error respectively. If the declaration constant $\gamma=0$, there is no decline in cumulative milk yield and the curve would be a straight line. Kamidi (2005) reported that the percentile scale of the persistency can be calculated as follows:

$$
\text { Persistency } \%=100(1+2 \gamma) \text { where } \gamma<0
$$

This part of study determined the persistency parameters and persistency as percentages for different herds, the season of calving and season of production. The heritability $\left(\mathrm{h}^{2}\right)$ was then estimated for the different persistency traits, using univariate animal model with the AIREML algorithm of the WOMBAT program (Meyer, 2007).

\section{Results and Discussion}

Mean of age at calving and average daily milk yield for all animals were $24.70 \pm 1.39$ months and $29.69 \pm 6.74 \mathrm{~kg}$ and the minimum and maximum daily milk yield of these traits was from 18.02 to 32.1 months and 2.5 to $60 \mathrm{~kg}$ respectively. The structure of the dataset and pedigree after editing is summarized in Table 1.

Table 1. Statistical characteristics of the edited dataset.

No. of cows

No. of sire

No. of dam

43528

2309

No. of herds

Year of calving

2001-2010

No. of sires

without offspring

42466
Average No.

progeny/dam

Average No.

progeny/sire

No. of sires with

offspring
659

435390

1.12

Age at calving:

Milk yield: 


$\begin{array}{lclc}\text { Average (month) } & 24.70 & \text { Average }(\mathrm{kg}) & 29.69 \\ \begin{array}{l}\text { *SD (month) } \\ \text { Maximum }\end{array} & 1.39 & \mathrm{SD}(\mathrm{kg}) & 6.74 \\ \begin{array}{l}\text { (month) } \\ \text { Minimum } \\ \text { (month) }\end{array} & 32.1 & \text { Maximum (kg) } & 60 \\ & 18.02 & \text { Minimum (kg) } & 2.5\end{array}$

*standard deviation

The Wood model is one of the best functions reported in the literature to describe the lactation curve of dairy cattle (Rekik et al., (2003); Gradiz et al., (2009); Elahi Torshizi et al., (2011). Milk production is largely dependent on the shape of the lactation curve and elements of the lactation, for example, peak yield and persistency. Description statistics of the Wood lactation curve parameters and the different persistency measures used in this study are shown in Table 2.

Table 2. Statistical description of the Wood model parameters and different persistency measures in the edited dataset of Iranian Holstein cattle.

\begin{tabular}{lcccccc}
\hline Parameters & Mean & Min & Max & SE & SD & CV \\
\hline a & 16.365 & 5.001 & 46.203 & 0.029 & 6.546 & 40.002 \\
b & 0.230 & 0.001 & 0.821 & 0.000 & 0.118 & 51.669 \\
c & 0.003 & 0.000 & 0.267 & 0.000 & 0.001 & 55.520 \\
$\begin{array}{l}\text { Peak time } \\
\text { (day) }\end{array}$ & 80.530 & 25.011 & 149.998 & 0.123 & 27.301 & 33.897 \\
$\begin{array}{l}\text { Peak yield (kg) } \\
\text { Part1 }\end{array}$ & 33.250 & 9.223 & 57.515 & 0.025 & 5.593 & 16.823 \\
& & & & & & \\
\end{tabular}




\section{MlMacrothink}

Journal of Agricultural Studies

ISSN 2166-0379

2016, Vol. 4, No. 3

$\begin{array}{lcccccc}\text { Part2 } & 3073.190 & 558.281 & 5593.023 & 2.614 & 578.511 & 18.824 \\ \text { Part3 } & 2721.810 & 94.955 & 5317.091 & 2.965 & 656.032 & 24.102 \\ & & & & & & \\ \text { Milk305 days } & 8774.710 & 2097.260 & 15596.123 & 7.338 & 1623.65 & 18.503 \\ & & & & & & \\ \text { Per1\% } & 103.166 & 24.223 & 138.081 & 0.044 & 9.922 & 9.617 \\ & & & & & & \\ \text { Per2\% } & 91.382 & 2.703 & 132.371 & 0.074 & 16.534 & 18.094 \\ & & & & & & \\ \text { Per3\% } & 87.890 & 11.160 & 104.968 & 0.045 & 10.099 & 11.490\end{array}$

a: initial milk yield, b: inclining slope parameter up to peak yield, c: declining slope after peak yield, SE: standard error, SD: standard deviation; CV: coefficient of variation.

The mean parameters of initial milk level (a), the rising phase of the curve (b) and the pattern of the decline in milk production at time $\mathrm{t}(\mathrm{c}) \pm$ standard deviation are $16.36 \pm 6.546,0.23 \pm$ 0.118 and $0.003 \pm 0.001$ respectively. Parameter $\mathrm{c}$ had the highest maximum coefficient of variation, followed by parameter $\mathrm{b}$ and lastly parameter $\mathrm{a}$. The average peak time and yield in this study were $80.530 \pm 0.123$ days and $33.250 \pm 0.025 \mathrm{~kg}$. This result showed that $\mathrm{CV}$ of peak time is twice that of peak milk yield. Average milk production in part 1, 2 and 3 are $2979.712,3073.190$ and $2721.810 \mathrm{~kg}$, respectively. The highest milk production was observed in part 2 , which was $35 \%$ of the total milk yield. The lowest cumulative milk yield was observed during part3 of lactation (31\% of the total 305 days milk yield). The average of Per1\% was higher than that of Per2\% and Per3\% (103.16 vs. 91.38 and 87.89 respectively). This indicates that persistency of production between 101- 200 days in milk is higher than that of 201 - 305 days in milk. Cakilli and Gunes (2011) reported persistency ratios of 91.93 and 59.91 respectively, for Brown Swiss cows. Per3\% has the lowest persistency because partial milk yield of Part3 is the lowest. The decrease in persistency can, therefore, be attributed to low milk production at the end of lactation.

Table 3 shows the phenotypic correlations between persistency measures, total 305 days milk yield and different partial productions. The highest phenotypic correlation was obtained between Part2 and 305 days milk yield. Persistency is particularly important for total yield. Phenotypic correlations among different persistency measures were positive as well which means the performances of persistency measures were high. The persistency measures based on ratios and variation are positively and negatively correlated with total yield respectively (Mostert et al., 2008). Phenotypic correlation between different persistency measures and 305 days milk in this study, ranged from 0.424 to 0.442 . According to Jakobsen et al., (2002) a good persistency measure should have high heritability and must be uncorrelated with 305 days milk yield because there is antagonist relationship between persistency and 305 days milk yield. 


\section{Macrothink}

Journal of Agricultural Studies

ISSN 2166-0379

2016, Vol. 4, No. 3

Table 3. Phenotypic correlations between partial milk yields and different persistency measures of Iranian Holstein cattle.

\begin{tabular}{|c|c|c|c|c|c|c|}
\hline & Part2 & Part3 & $\begin{array}{c}\text { Milk305 } \\
\text { days }\end{array}$ & Per $1 \%$ & Per2\% & Per3\% \\
\hline Part1 & 0.886 & 0.663 & 0.884 & -0.017 & -0.013 & 0.0087 \\
\hline Part2 & & 0.914 & 0.990 & 0.476 & 0.435 & 0.355 \\
\hline Part3 & & & 0.934 & 0.644 & 0.722 & 0.688 \\
\hline Milk305 days & & & & 0.424 & 0.442 & 0.437 \\
\hline Per $1 \%$ & & & & & 0.906 & 0.707 \\
\hline Per2\% & & & & & & 0.929 \\
\hline
\end{tabular}

The results of Tables 2, 3 and 4 showed that Per1\% was better than the other measures for evaluation of persistency. Heritability estimates for partial, total 305 days milk yield and different persistency measures are given in Table 4. Part2 and Part3 have the highest $(0.307 \pm$ $0.015)$ and lowest $(0.232 \pm 0.014)$ heritabilities for partial milk yield, respectively, and the heritability estimates for 305 days milk yield was $0.305 \pm 0.005$, which is similar to those obtained by Khorshidie et al., (2012), Cobuci et al., (2005) and Biassus et al., (2010). The level of milk yield has an important influence on persistency. The first parity cows have lower peak, flatter lactation curve, and higher persistency, than cows in later lactations.

Heritability estimates for different persistency indicators based on the ratios in this study were low and ranged from 0.062 to 0.084 (Table 4). Atashi et al., (2006) showed that heritability of persistency is low to medium in Iranian Holstein cattle. The criteria in that study were the maximum production of all test-day records per lactation divided by the related mean, the percentage of daily milk retained from the peak to the end of lactation, standard deviation of all test-day records of complete lactation, The latest test-day record yield divided by the mean of all test-day records and a criterion that was proposed by the Wood function. The heritabilities for Per $1 \%$, Per2\% and Per3\% found in this study are lower than those reported by Yilmaz and Koc (2013). They reported $0.19 \pm 0.07,0.31 \pm 0.07$ and $0.28 \pm 0.07$ for heritabilities of Per $1 \%$, Per $2 \%$ and Per3\% in Red Holstein cows raised under Mediterranean climate condition. Jakobsen et al., (2002) obtained values from 0.09 to 0.24 for persistency of milk yield while Cole and VanRaden (2006) reported heritabilities ranging from 0.10 to 0.11 for persistency of milk yield. Different heritabilities of persistency can be attributed to differences in the definition of the trait and differences in statistical methods 


\section{Macrothink}

Journal of Agricultural Studies

ISSN 2166-0379

2016, Vol. 4, No. 3

used in the calculation of persistency (Biassus et al., 2010; Jakobsen et al., 2002). According to Jakobsen et al., (2002) a good persistency measure should have a high heritability and must be uncorrelated with 305 days milk yield because there is an antagonistic relationship between persistency and 305 days yield.

Table 4. Heritabilities of partial milk yields and different measures of persistency of Iranian Holstein cattle.

\begin{tabular}{lc}
\hline trait & $\mathrm{h}^{2} \pm \mathrm{SE}$ \\
\hline Part1 & $0.272 \pm 0.014$ \\
Part2 & $0.307 \pm 0.015$ \\
Part3 & $0.232 \pm 0.014$ \\
Milk305 days & $0.305 \pm 0.005$ \\
Per1\% & $0.084 \pm 0.009$ \\
Per2\% & $0.080 \pm 0.009$ \\
\hline Per3\% & $0.062 \pm 0.007$ \\
\hline
\end{tabular}

Phenotypic trends for Per1\%, Per2\%, Per3\% and 305 days milk yield over 11 birth years (from 2001 to 2011) are shown in Figure 1. There was an increasing phenotypic trend for 305 days milk yield during these years. This result is similar to those reported by Farhangfar and Naeemipour (2007), who found an annual increase of $137.152 \mathrm{~kg}$ milk during 1991- 2001 for Iranian Holstein cows. Phenotypic trends of the various persistency measures show an increasing trend over the years (Figure 1). The Per $1 \%$ trend is on a higher level of persistency compared to the Per2\% and per3\% trends. Due to the level of milk production being higher in mid-lactation compared to that of the beginning and end of lactation, the persistency of milk production is highest and lowest in Per1\% and Per3\% respectively. The level of milk production being higher in mid lactation compare to that of the beginning and end of lactation. Various factors seem to influence persistency such as herd, the season of production and calving, age at calving, pregnancy status, and especially parity. In Table 5 least square means of different environmental factors affecting on Per $1 \%$, Per2\% and Per3\% are shown.

Table 5. Least square means \pm SE of environmental factors affecting the different persistency measures of Iranian Holstein cows. 
Factor

Per1\%

Per2\%

Per3\%

Production season

Spring

$100.316 \pm 0.220$

$87.145 \pm 0.367$

$86.018 \pm 0.226$

Summer

$100.329 \pm 0.220$

$88.346 \pm 0.367$

$86.735 \pm 0.226$

Autumn

$101.685 \pm 0.216$

$89.631 \pm 0.361$

$87.334 \pm 0.222$

Winter

$100.947 \pm 0.218$

$87.693 \pm 0.364$

$86.080 \pm 0.224$

Calving season

Spring

$100.302 \pm 0.221$

$87.552 \pm 0.368$

$86.456 \pm 0.226$

Summer

$101.226 \pm 0.219$

$88.996 \pm 0.365$

$87.042 \pm 0.225$

Autumn

$101.342 \pm 0.218$

$88.446 \pm 0.363$

$86.473 \pm 0.224$

Winter

$100.908 \pm 0.218$

$87.822 \pm 0.363$

$86.196 \pm 0.224$

Calving year

2001

$98.868 \pm 0.323$

$85.170 \pm 0.539$

$85.354 \pm 0.332$

2002

$100.126 \pm 0.246$

$86.379 \pm 0.411$

$85.483 \pm 0.253$

2003

$99.2230 \pm 0.228$

$85.239 \pm 0.379$

$85.092 \pm 0.234$

2004

$100.229 \pm 0.226$

$86.991 \pm 0.377$

$86.015 \pm 0.232$

2005

$101.198 \pm 0.220$

$88.870 \pm 0.367$

$87.026 \pm 0.226$

2006

$100.855 \pm 0.219$

$88.271 \pm 0.365$

$86.676 \pm 0.225$ 
2007

2008

2009

2010
$102.643 \pm 0.216$

$102.311 \pm 0.205$

$102.585 \pm 0.204$

$101.406 \pm 0.237$
$91.118 \pm 0.360$

$88.017 \pm 0.222$

$90.613 \pm 0.342$

$87.772 \pm 0.210$

$91.138 \pm 0.341$

$88.056 \pm 0.210$

$88.250 \pm 0.394$

$85.927 \pm 0.243$

The significant influences of herd and season of production show the importance of various management strategies, nutritional and disease statues, selective breeding and climate conditions on milk production of dairy cattle (Ilatsia et al., 2007; Tekerli et al., 2000). The season in which the lactation started (season of calving) had an important effect on persistency. Calving season causes differences in milk production, the shape of lactation curve and its parameters such as persistency. Optimum persistency of milk yield (Per1\%) is higher for cows calving in summer and autumn compared to that of cows calved in spring and winter (101.22 and 101.34 vs, 100.30 and 100.90 respectively). Persistency was greatest during the warmer season. This is in agreement with the result of Yilmaz and Koc (2013) who reported that in the warm season of calving, lower milk yield at the beginning of lactation is responsible for higher persistency. They also suggested that cows that calved in winter have higher milk production early in lactation and show lower persistency.

Table 6. Model fit of total milk yield data fitted to average quadratic curves for different calving and production seasons and calving year.

\begin{tabular}{lcccc}
\hline factor & $\begin{array}{l}\text { Declaration } \\
\text { constant }(\gamma)\end{array}$ & $\beta$ & RMSE & Persistency\% \\
\hline $\begin{array}{l}\text { Production } \\
\text { season }\end{array}$ & & & & \\
Spring & -0.0056 & 6.4032 & 1573.349 & 98.88 \\
Summer & -0.0011 & 2.8973 & 1641.570 & 99.78 \\
Autumn & -0.0029 & 4.7231 & 1619.121 & 99.42 \\
Winter & -0.0052 & & & 98.96 \\
\hline
\end{tabular}

Calving season 


\section{Macrothink Institute}

Journal of Agricultural Studies

ISSN 2166-0379 2016, Vol. 4, No. 3

$\begin{array}{lcccc}\text { Spring } & -0.0057 & 6.3538 & 1574.778 & 98.86 \\ \text { Summer } & -0.0001 & 2.1439 & 1656.969 & 99.28 \\ \text { Autumn } & -0.0036 & 5.2281 & 1598.757 & 99.98 \\ & & & & \\ \text { Winter } & -0.0061 & 7.3032 & 1576.328 & 98.87\end{array}$

Calving year

2001

$-0.0078$

$-5.1651$

1564.763

98.44

2002

$-0.0044$

$-1.8134$

1463.238

99.12

2003

$-0.0107$

10.9669

1434.065

97.86

2004

$-0.0139$

12.8433

1459.926

97.22

2005

$-0.0121$

12.4534

1434.082

97.58

2006

$-0.0117$

12.8596

1509.987

97.66

2007

$-0.0091$

10.3964

1551.073

98.18

2008

$-0.0121$

12.8668

1540.072

97.58

2009

$-0.0154$

14.2543

1550.099

96.92

2010

$-0.0232$

13.8340

1649.549

95.36

Changes in Per1\% with the age of the cows at first calving are presented in Figure 2. This figure shows that with an increase in age at first calving from 18 to 32 month in primiparous cow, persistency decreases. This means that persistency of lactation between 101-200 days (part2) is higher than that of 201 to 305 days (part3). The rate of decreasing from 18 to 27 months of age at calving is only moderate but after that, a rapid decline in Per1\% was observed. The cows that calved earlier shows lower peak yield $(25 \mathrm{~kg})$ in later peak time (85 days) compared to cows that calve after 27 months. The latter cows showed higher peak yield $(31 \mathrm{~kg}$ ) in the early time of peak (75 days). So, total milk production of part 2 in late calving cows is lower than cows which calved in earlier ages and this is the reason for severe decline 


\section{Macrothink}

in persistency of cows with late age at first calving.

The result of fitting cumulative milk yield to the curvilinear model including deceleration constants, residual mean square error and persistency levels in different seasons of production and calving are presented in Table 6. Perfect fit of cumulative milk yield was obtained for systematic environmental effects (because of the high rate of persistency in different calving, production seasons and calving year). The persistency of lactation was also calculated in different herds and seasons of calving and production. The results showed that the persistency values calculated by the Kamidi model are similar to that of Per1\%. The results of the parameters in Table 6 including $\beta, \gamma$ and Persistency\% are similar to findings of Kamidi (2005). These estimates of persistency indicate that persistency of primiparous cows calving in cold seasons (autumn and winter) are similar to cows calving in warm seasons in Iran.

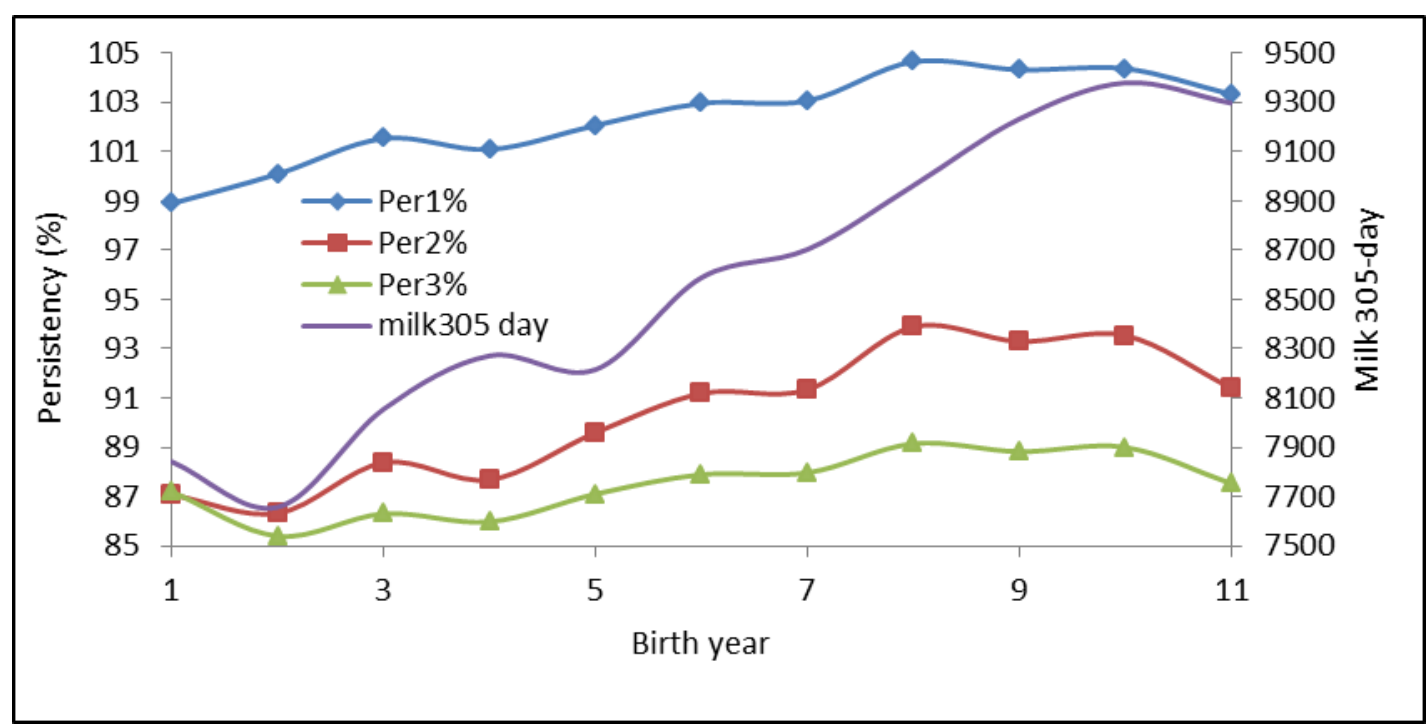

Figure 1. Average persistency measures and milk 305 days per year of birth for Iranian Holstein cows. 


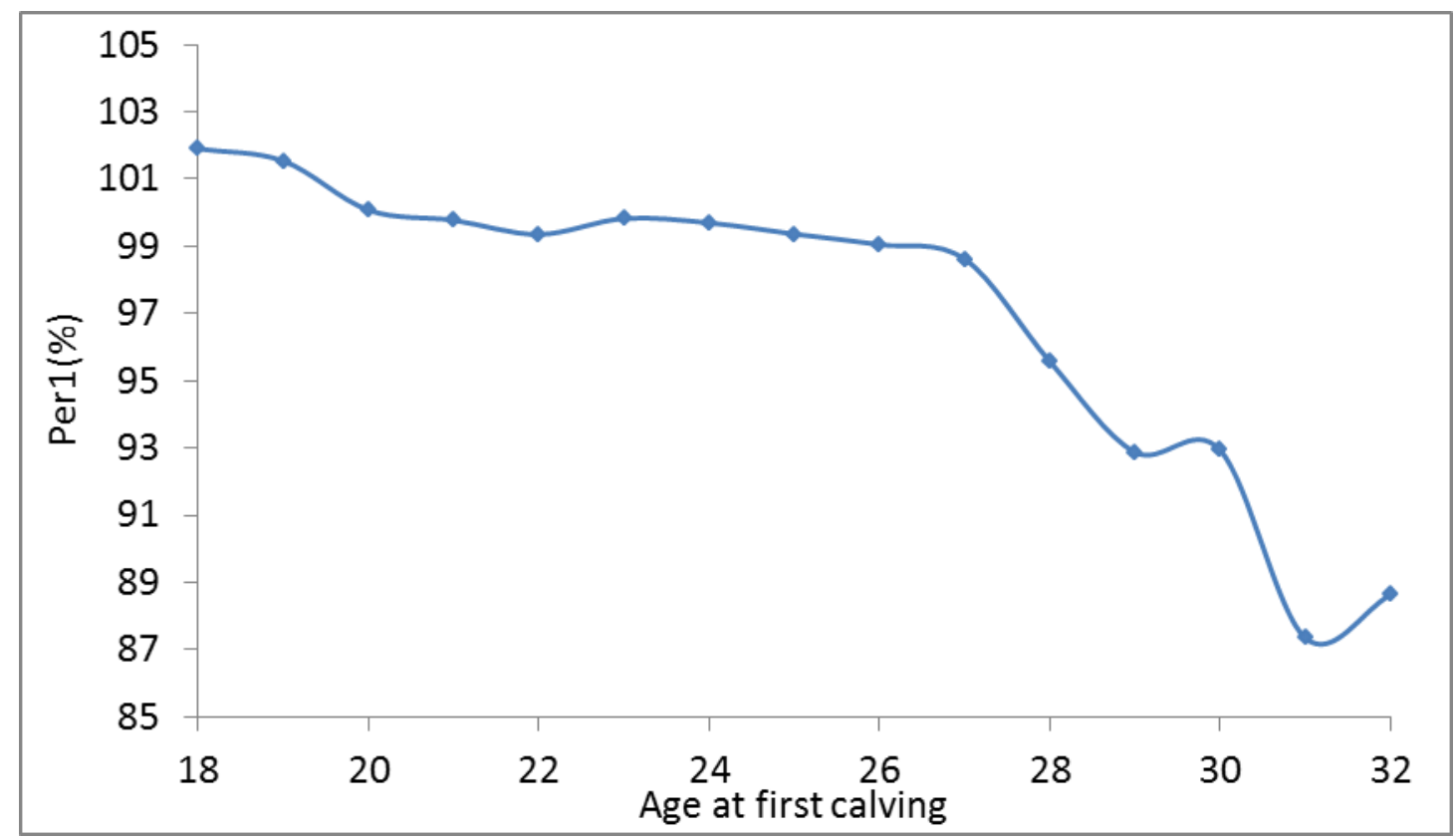

Figure 2. Phenotypic trend of Per1\% in different ages at first calving for Iranian Holstein cattle.

The comparison of persistency in different calving years in Table 5 and 6 showed irregular changes in persistency during different calving years. Variation in persistency among different systematic factors using a quadratic curve, are clearly related to both the Declaration constant $(\gamma)$ and especially $\beta$. These results are close to that result of Khazaei and Nikosair (2008). They reported that persistency of lactation obtained by a curvilinear model is more accurate than that obtained by the Wood model, but it seems that calculation of persistency based on partial milk yield (Per1\%) is more accurate than that of Per2\%, Per3\% and the curvilinear model. This is in agreement with results of Cakilli and Gunes (2011) who stated that Per $1 \%$ is higher compared to other measures of persistency in young Brown Swiss cattle in Turkey. Mendez et al., (2013) reported that the persistency based on (M200-M100)/M100)*100 was the best result in buffaloes in Cuba. In this method, M200 and M100 are total productions from 1-200 and 1-100 days in milk, respectively. Jakobsen et al., (2002) reported that deviation of milk yield from 60 to 280 days in milk is a good choice for calculation of persistency, while Togashi and Lin (2004) proposed the ratio of EBV280 to EBV65 day as good criteria for improving persistency. The main drawback of calculation of persistency by the curvilinear method is that it cannot be used for individual cows and it is therefore only specific for calculation of persistency for a group of animals or classification systematic environmental effects

\section{Conclusion}

Persistency of lactation is considered a very important characteristic of the lactation curve which can be significantly affected by some environmental factors such as herd, the season of production, the season of calving, parity, age at calving and other systematic effects. The Per1\% measure was preferred in the selection of animals for milk yield persistency. This measure showed the highest heritability and the lowest phenotypic correlation with 305 days 
milk yield in this study. The persistency of milk yield is slightly higher in warm seasons. Perfect fits of total milk yield to curvilinear model, systematic environmental effects and persistency were obtained using this model. Increasing age at first calving from 18 to 32 months decreases the persistency of milk yield. This is related to peak time and peak yield at different age of calving, which has seriously affect persistency of milk yield.

\section{Acknowledgement}

The center of animal breeding of Iran is greatly acknowledged for supplying the data used in this study.

\section{References}

Atashi, H. M., Moradi S., \& Abdolmohammadi, A. (2006). Study of some suggested measures of milk yield persistency and their relationships. International Journal of Agriculture and Biology, 3, 387-390. www.fspublishers.org/published_papers/63902_.pdf.

Biassus, I. D. O., J. A. Cobuci, J. A. Costa, P. R. N. Rorato, J. B. Neto., \& Cardoso, L. L. (2010). Persistence in milk, fat and protein production of primiparous Holstein cows by random regression models. Revista. Brasileira de Zootecnia. 39: 2617-2624. http://dx.doi.org/10.1590/S1516-35982010001200009 .

Cakilli, F., \& Gunes, H. (2011). Some factors affecting on persistency of lactation milk yield in Brown Swiss cattle. [Online] available: http://vetjournal.istanbul.edu.tr/ fulltexthtml/2012-2/89-95.htm (March 3, 2011).

Cobuci, J. A., Euclydes, R. F., Lopes, OS., Costa, C. N., Torres, R. A., \& Pereira, C. S. (2005). Estimation of genetic parameters for test-day milk yield in Holstein cows using a random regression model. Genetics and Molecular Biology, 28, 75-83.http://dx.doi.org/10.1590/S 1415-47572005000100013.

Cole, J. B., \& VanRaden, P. M. (2006). Genetic evaluation and best prediction of lactation persistency. Journal of Dairy Science. 89:2722-2728.http://dx.doi.org/10.3168/jds.S0022-130 2(06)72348-7.

Dedkova, L., \& Nemcova, E. (2003). Factors Affecting the Shape of Lactation Curves of Holstein Cows in the Czech Republic. Czech Republic Journal of Animal Science, 48, 395-402.

Druet, T., F. Jaffrézic., \& Ducrocq, V. (2003). Modeling of lactation curves and estimation of genetic parameters for first lactation test-day records of French Holstein cows. Journal of Dairy Science. 86: 2480-2490. http://dx.doi.org/10.3168/jds.S0022-0302(03)73842-9.

Elahi Torshizi, M., A. A. Aslamenejad., M. R. Nassiri., \& Farhangfar, H. (2011). Comparison and evaluation of mathematical lactation curve functions of Iranian primiparous Holsteins. South African Journal of Animal Science.41:104-115.http://www.sasas.co.za/comparison-and-evaluation-mathematical-lactation-curve-functions-iranian-primiparous-holsteins.

Elahi Torshizi, M., A. A. Aslamenejad., M. R. Nassiri., H. Farhangfar., J. Solkner., M. Kovac., Meszaros, G., \& Malovrh, S. (2013). Analysis of test day milk yield by random regression models and evaluation of persistency in Iranian dairy cows. Iranian Journal of Applied Animal Science, 3(1), 67-76. http://ijas.iaurasht.ac.ir/article_514242_110670.html

Gengler, N. (1996). Persistency of lactation yields: A review. Interbull Bulletin, 12, 97-102. https://journal.interbull.org/index.php/ib/article/view/254.

Gradiz, L., L. Alvarado, A. K. Kahi., \& Hirooka, H. (2009). Fit of Wood's to daily milk 
records and estimation of environmental and additive and non-additive genetic effects on lactation curve and lactation parameters of crossbreed dual purpose cattle. Livestock Science. 124: 321-329. http://dx.doi.org/10.1016/j.livsci.2009.02.016.

Farhangfar, H., \& Naeemipour, H. (2007). Phenotypic study of lactation curve in Iranian Holstein. Journal of Agriculture Science and Technology. 9: 279-286. https://jast.modares.ac. ir/article_4444_942.html.

Hickson, R. E., N. Lopex-Villalobos., \& Dalley, D. E. (1996). Yields and persistency of lactation in Friesian and Jersey cows milked once daily. Journal of Dairy Science. 89: 2017-2024. http://dx.doi.org/10.3168/jds.S0022-0302(06)72269-X.

Ilatsia, E. D., T. K. Muasya, W. B. Muhuyi., \& Kahi, A. K. (2007). Genetic and phenotypic parameters for test day milk yield of Sahiwal cattle in the semi-arid tropics. Animal. 1: 185-192. http://dx.doi.org/10.1017/S175173110739263X.

Jakobsen, J. H., P. Madsen, J. Jensen, J. Pedersen, L. G. Christensen., \& Sorensen, D. A. (2002). Genetic parameters for milk production and persistency for Danish Holstein estimated in random regression models using REML. Journal of Dairy Science, 85, 1607-1616.http://dx.doi.org/10.3168/jds.S0022-0302(02)74231-8.

Jamrozik, J., L. R. Schaeffer., \& Dekkers, J. C. M. (1997). Genetic evaluation of dairy cattle using test day yields and random regression model. Journal of Dairy Science, 80, 1217-1226. http://dx.doi.org/10.3168/jds.S0022-0302(97)76050-8.

Jensen, J. (2001). Genetic evaluation of dairy cattle using test day models. Journal of Dairy Science, 84, 2803-2812. http://dx.doi.org/10.3168/jds.S0022-0302(01)74736-4.

Kamidi, R. E. (2005). A parametric measure of lactation persistency in dairy cattle. Livestock. Science, 96, 141-148. http://dx.doi.org/10.1016/j.livprodsci. 2004.11.042.

Kaygisız, A., G. Bakır., \& Yener, S. M. (1995). Genetic and phenotypic parameter estimation of persistency of milk yield in Holstein- Friesian cows. Turkish Journal of Veterinary and Animal Science, 19 (4), 259-263.

Khazaei, J., \& Nikosair, M. (2008). Approximating milk yield and milk fat and protein concentration of cows through the use of mathematical and artificial neural networks models. [Online] available: cabi.org/gara/fulltext pdf/2008/20083298113.pdf. (March 2, 2008).

Kheirabadi, K., \& Alijani, S. (2014). Genetic parameters for milk production and persistency in Iranian Holstein population by the multitrait random regression model. Archive Tierzucht, 12(57), 1-12. http://arch-anim-breed.fbn-dummerstorf.de/content/2014/cont2014.html.

Khorshidi, R., A. A. Shadparvar, N. Ghavi Hossein-zadeh., \& Joezy Shakalgurabi, S. (2012). Genetic trends for 305-day milk yield and persistency in Iranian Holsteins. Livestock Science. 144: 211-217. http://dx.doi.org/10.1016/j.livsci.2011.11.016.

Macciotta, N. P. P., F. Miglior., Cappio-Borlino., A., \& Schaeffer, L. R. (2007). Fit of different functions to the individual deviations in random regression test day models for milk yield in dairy cattle. Italian Journal of Animal Science.6: 153-155. http://www.tandfonline.com/doi/abs/10.4081/ijas.2007.1s.153.

Meyer, K. (2007). WOMBAT - A tool for mixed model analyses in quantitative genetics by REML, J. Zhejiang Uni. Science B, 8, 815-821.

Mostert, B. E., R. P. Vannder, W., \& Theron, H. E. (2008). Procedures for estimation of genetics persistency indices for milk production for the South African dairy industry. South 


\section{$\Lambda$ Macrothink}

Journal of Agricultural Studies

ISSN 2166-0379 2016, Vol. 4, No. 3

African journal of Animal Science, 38, 224-230. http://www.ajol.info/index.php/sajas/article/ view/4128.

Rekik, B., A. BenGara, M. Ben Hamouda., \& Hammami, H. (2003). Fitting lactation curves of dairy cattle in different types of herds in Tunisia. Livestock Science, 83, 309-315. http://dx.doi.org/10.1016/S0301-6226(03)00028-9.

Tekerli, M., Z. Akinci, J. Dogan., \& Akcan, A. (2000). Factors affecting the shape of lactation curves of Holstein cows from the Balikesir Province of Turkey. Journal of Dairy Science. 83:1381-1386. http://dx.doi.org/10.3168/jds.S0022-0302(00)75006-5.

Togashi, K., \& Lin, C. Y. (2004). Efficiency of different selection criteria for persistency and lactation milk yield. Journal of Dairy Science, 87, 1528-1535. http://dx.doi.org/10.3168/jds .S0022-0302(04)73304-4.

Togashi, K., \& Lin, C. Y. (2006). Selection for milk production and persistency using eigenvectors of the random regression coefficient matrix. Journal of Dairy Science, 89, 4866-4873. http://dx.doi.org/10.3168/jds.S0022-0302(06)72535-8.

Togashi, K., C. Y. Lin, Y. Atagi, K. Hagiya., \& Nakanishi, T. (2008). Genetic characteristics of Japanese Holstein cows based on multiple lactation random regression test day animal model. Livestock Science. 114: 194-201. http://dx.doi.org/10.1016/j.livsci.2007.04.023

Solkner, J., \& Fuchs, W. (1987). A Comparison of different measures of persistency with special respect to variation of test-day milk yields. Livestock Science, 16, 305-319.

Strabel, T., W. Kopacki., \& Szwaczkowski, T. (2001). Genetic evaluation of persistency in random regression test day models. Interbull Bulletin No. 27, 189-192.

Wood, P. D. P. (1967). Algebraic model of the lactation curve in cattle. Nature, 216, 164-165.

http://www.nature.com/nature/journal/v216/n5111/abs/216164a0.html.

Yilmaz. H., \& Koc, A. (2013). A research on milk yield, persistency, milk constituents and somatic cell count of red Holstein cows raised under Mediterranean climate conditions. Bulgarian Journal of animal Science, 19(6), 1401-1407. www.agrojournal.org/19/06-35.pdf Zimmermann, E., \& Sommer, H. (1973). Zum laktationsverlauf von kuehen in hochleistungsherden und dessen beeinflussung durch nichterbliche Faktoren. Zuechtungskunde, 45, 75-88.

\section{Copyright Disclaimer}

Copyright for this article is retained by the author(s), with first publication rights granted to the journal.

This is an open-access article distributed under the terms and conditions of the Creative Commons Attribution license (http://creativecommons.org/licenses/by/3.0/). 